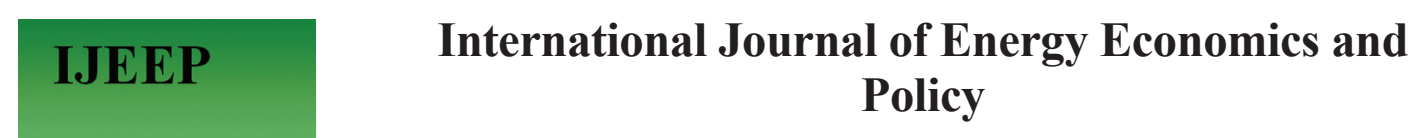

ISSN: $2146-4553$

EJ Ecomburmal

available at http: www.econjournals.com

International Journal of Energy Economics and Policy, 2021, 11(5), 99-105.

\title{
Development of Biofuels Research in South Africa
}

\author{
Donaji Jiménez-Islas ${ }^{1 *}$, Miriam Edith Pérez-Romero ${ }^{2,3}$, Ignacio Ventura Cruz ${ }^{4}$, \\ Martha Beatriz Flores-Romero ${ }^{2}$
}

${ }^{1}$ Higher Technological Institute of Huichapan, Renewable Energy Division, Biofuels, El Saucillo, Huichapan, Mexico, ${ }^{2}$ Michoacan University of San Nicolas of Hidalgo, Faculty of Economic and Administrative Sciences, Ciudad Universitaria, Morelia, Mexico, ${ }^{3}$ Higher Technological Institute of Huichapan, Business Management Division, El Saucillo, Huichapan, Mexico, ${ }^{4}$ Higher Technological Institute of Huichapan, Mechatronic Division, El Saucillo, Huichapan, Mexico. *Email: djimenez@iteshu.edu.mx

Received: 29 March 2021

Accepted: 19 June 2021

DOI: https://doi.org/10.32479/ijeep.11454

\begin{abstract}
The global biofuels have attracted a lot of attention because of their potential as a clean and renewable source of energy. The bibliometric method has been used for providing quantitative assessment of the field of biofuels research in South Africa. Data used in this study were obtained from Scopus database. The research covers such topics as the publications and citations, the document type, journals, leading authors, institutions, subjects, areas and keywords. The publications and citations data fitted the Gompertz model to find out the growth rate. Two stages in the evolution of publications and citations were found and coincide with the exponential behaviour. Biofuels research was identified to have an exponential growth from 2011 with a growth rate of 0.2628 years $^{-1}\left(\mathrm{R}^{2}=0.93\right)$. This study demonstrates that the most documents were published in high-impact journals. Researchers would benefit from the findings because they would be able to see a trend in biofuels research in South Africa.
\end{abstract}

Keywords: Bioethanol, Biogas, Biofuel, Biodiesel

JEL Classifications: Q16, Q20, Q42

\section{INTRODUCTION}

The primary cause of anthropogenic greenhouse gas pollution is fossil fuels. As a society, we need solutions for good food security and environmental quality. The renewable energy as part of the solution to reduce the $\mathrm{CO}_{2}, \mathrm{CO}, \mathrm{NOx}$ and others emissions (EdwinGeo et al., 2021). Renewable energy sources are critical for economic growth because they ensure energy efficiency (Bórawski et al., 2019). There are various sources of renewable energy such as solar, wind, hydro, thermal and biomass (Sameeroddin et al., 2021). Biofuels are derived from plants and other biological materials such as feedstock or biomass (Albashabsheh and Stamm, 2021), these materials are considered environment friendly and renewable sources and have a large share in the production of energy from renewable sources (Beigzadeh et al., 2021). Blending mandates, excise tax exemptions and incentives, clean or low carbon fuel requirements, fiscal incentives, and public financing have been developed and introduced to promote the production of biofuels (Ebadian et al., 2020). In this context, South Africa has also developed a number of policies aimed at promoting the production and use of biomass fuels, as well as attracting investment into rural agricultural growth and creating new jobs, but biofuels have yet to be commercially generated in large quantities (Pradhan and Mbohwa, 2014). In recent years, assessing the state of the art in a scientific discipline has become increasingly common, owing to the advancement of computers and the Internet (Merigó and Yang, 2016). Researchers conducted on South African institutions has covered a wide range of biofuels and it is necessary to assessment the evolution of publications to determine the potential of the scientific community and the pertinence of public policy. A bibliometric analysis can provide information on the growth trends and characteristics of research outputs (Chuang 
et al., 2011). Also, bibliometrics is a field of study that examines bibliographic content from a quantitative perspective (Merigó et al., 2015). There are numerous bibliometric studies that show the collaborative role of south Africa in the energy field, among which we find: Mapping and comparative assessment of the field of energy and fuels research in South African higher education institutions (Pouris, 2008); the assessment, the energy and fuels research in South Africa from 2003 to 2013, with emphasis on fossil and renewable energy (Pouris, 2016); the bibliometric analysis of energy publications from Nigeria researchers from 1974 to 2019 with the highest collaboration was with the South Africa researchers (Adedayo et al., 2021). The previous studies show a global vision of energy in South Africa, however it is necessary to assist the research communities towards predicting the dynamic changes that could occur in the biofuels energy field for future prospects. Also, findings from this study may be important in assisting policymakers in South Africa.

To fill the research gap in previous articles, the aim of the present study was to determine the South Africa biofuels research and its trends using a bibliometric analysis to quantitatively and qualitatively evaluate the publications in the Scopus database from 1989 to 2020. Specifically, we analysed it in order to identify trends over time of; rate of growth to publications and citations of author; publication of institutions, document type, journals used for researchers, most cited authors, universities, areas, sponsors and keywords of South Africa in the biofuels field.

\section{MATERIALS AND METHODS}

\subsection{Dataset Used}

The publications dataset for this study was extracted on March 31, 2021, from the Scopus database. The keywords of the query (TITLE-ABS-KEY ("South Africa*") AND TITLE-ABS-KEY (bioethanol) OR TITLE-ABS-KEY (bio-ethanol) OR TITLEABS-KEY (biodiesel) OR TITLE-ABS-KEY (biogas) OR TITLEABS-KEY (biofuel*) OR TITLE-ABS-KEY (biomethan*) OR TITLE-ABS-KEY (bio-diesel)) were used to search for documents via Scopus from 1979 to 2020, and the information for the resulting for documents was downloaded as csv files. The sign $(*)$ in the search box was used to obtain both singular and plural of a keyword, and the marks (" ") were used for exact phrases search (Jiménez-Islas et al., 2021b). Ethical approval was not necessary, since the data were downloaded from the public databases and did not involve any interactions with human or animal subjects.

\subsection{Modeling and Statical Methods}

The publications and citations were analysed by fitting mathematical models with Microsoft Excel and the solver function. The Gompertz growth model was used to adjust the profile of documents in the field.

$$
\begin{array}{r}
P(y)=a e^{-b e^{-\mu t}} \text { Gompertz model } \\
\left(P_{(y)} \text { Scopus }-P_{(y)} \text { model }\right)^{2} \text { Normalization }
\end{array}
$$

Where the symbol $P(y)$ represents the cumulative volume of documents by year, " $\mu$ " the specific growth rate of publications,
" $a$ " the asymptotic publications, " $b$ " an integration constant related to initial publications, " $t$ " is time, $P_{(y)}$ Scopus publications reported on Scopus database and $P_{(y) \text { model }}$ estimated publications by model.

The data was used to fit all parameters using the "solver function on Microsoft Excel", the simulation program was designed to achieve the minimal normalized error using the solver function of Microsoft excel, and the data of Scopus was fitted to determine the value of specific growth rate $(\mu)$, the results of Scopus and the ones generated by model were analysed using a regression curve fitting with statistical significance $(\mathrm{P}<0.05)$ with data analysis of Microsoft Excel and it was estimated the determination coefficient $\left(\mathrm{R}^{2}\right)$. The data download from Scopus was imported into VOSviewer software which was used to create a keywords network map. The instructions are as follows: Create a map based on bibliographic data; read data from Scopus bibliometric database, files; type analysis with co-occurrence; unit of analysis with all keywords; full counting; maximum number of occurrences of a keyword (5), number of keywords to be selected (187); verify selected keywords and finish; visualization frames.

\section{RESULTS AND DISCUSSION}

The following section explicitly describes the results of the bibliometric analysis of the 352 documents found, published from 1979 to 2020 on the biofuels field in South Africa.

\subsection{The Biofuels Publications Trends in South Africa} The analysis of published scientific documents indicates that there is a growing interest in the topic related to the biofuels field. The first document was published in 1979 and its level remains below 10 until 2005, Figure 1. As can be observed, the research trends can be divided into two stages: (i) The first stage from 1979 to 2008, it was a stage which slowly increased and few documents were published on biofuels topics in South Africa. (ii) On second stage, the number of publications significantly increased from 2009 onwards.

Figure 1 shows the growth exponential in the number of publications each year, when the Gompertz model fits the data. The specific growth rate of publications value obtained was 0.2628 year $^{-1}$ with a determination coefficient $R^{2}=0.93$. The model can be used to determine the estimation of publications in the next years in South Africa. In terms of rate of publications, Argentina has a value of 0.20 year $^{-1}$, Chile 0.19 year $^{-1}$, Mexico 0.18 year $^{-1}$ and Colombia 0.22 year $^{-1}$, with values estimated with the Logistic model (Jiménez-Islas et al., 2021a), these references allow to compare the results with the present work.

\subsection{Citations of Publications of Biofuels in South Africa}

The citation represents the impact and the influence of the publication (Makhoba and Pouris, 2017). Figure 2 shows the citation trends of biofuels publications in South Africa, with a profile of two stages, in the first stage from 1979 to 2004 a few documents were cited. However, after 2013, there is an exponential growth in the number of citations, possibly caused by energy policies that try to reduce the number of $\mathrm{CO}_{2}$ emissions and 
Figure 1: Number of publications of biofuels in South Africa from 1979 to 2020. (o publications WoS; — model)

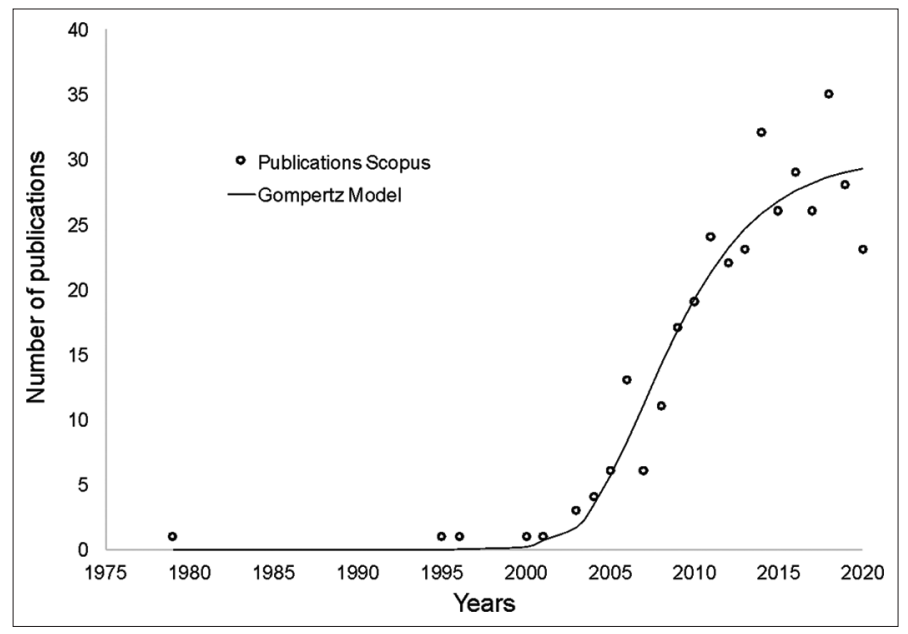

Figure 2: Number of publications of biofuels in South Africa from 1979 to 2020. ( o citations WoS; - model)

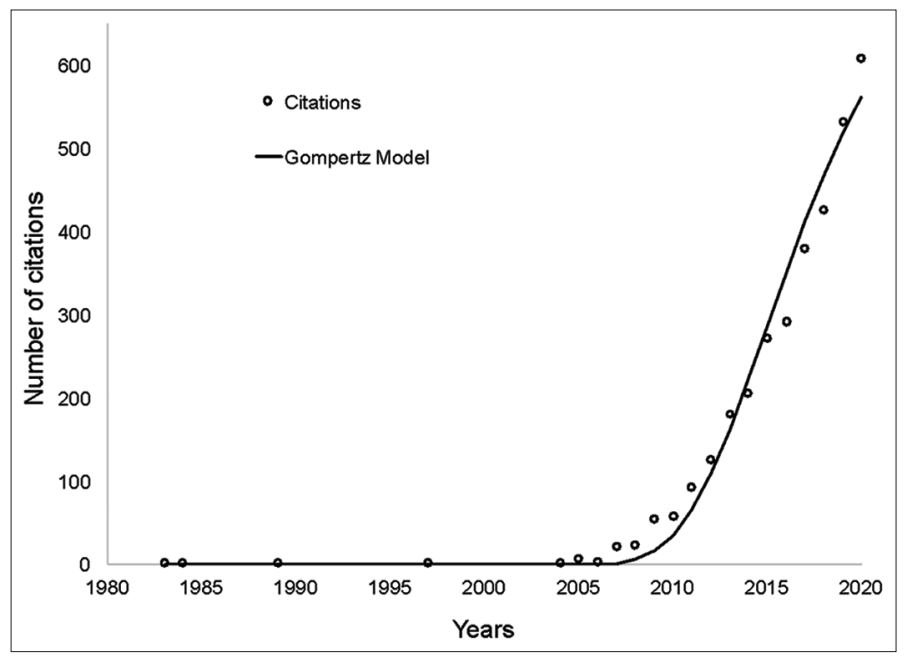

energy dependence. We found that the Gompertz model provides a reasonable fit to citation data, the Figure 2 shows results of the estimation. The fitted regression curve exhibited a $\mathrm{R}^{2}$ value of 0.98 and a specific rate growth of publications of 0.22 year $^{-1}$. With the growth in the number of citations, the impact of biofuel publications can be observed, in particular its incidence in South Africa.

\subsection{Type of Publications in Biofuels Field and Languages}

As English is a global language, most research documents were published in English (99.15\%), followed by German $(0.57 \%)$ and Italian $(0.28 \%)$, probably because most documents are published in international journals (Zhao et al., 2021; Chàfer et al., 2021). The analysis of the type of publications shows that most of them are articles (207), which represent $58.81 \%$ of the total documents; followed by conference papers, book chapters, reviews and others, Table 1.

\subsection{Journals with the Most Contribution in the Biofuels Field}

The ranking of the journals was made according to the number of publications found in the present research and the division between
Table 1: Number of research document type from South Africa in the field of biofuels

\begin{tabular}{lcc} 
Document type & Number of publications & Percentage of total \\
Article & 207 & 58.81 \\
Conference Paper & 67 & 19.03 \\
Book Chapter & 28 & 7.95 \\
Review & 25 & 7.10 \\
Conference Review & 8 & 2.27 \\
Note & 5 & 1.42 \\
Business Article & 4 & 1.14 \\
Book & 3 & 0.85 \\
Erratum & 3 & 0.85 \\
Editorial & 1 & 0.28 \\
Letter & 1 & 0.28 \\
\hline
\end{tabular}

the journals with the same number of publications was made according to the TC/TP ratio. Table 2 shows the top 15 journals used by South Africa researchers in the biofuels field, the first is occupied by the journal "Journal of Energy in Southern Africa", with 12 publications, a journal with quartile Q2. The journal "Lecture Notes in Engineering and Computer Science" is ranked $2^{\text {nd }}$, with the total of 12 publications. The table also shows that most are within quartile Q1-Q2 and they are international journals and from South Africa. The "Renewable and Sustainable Energy Reviews" and "Biomass and Bioenergy" are the journals most cited with 314 y 173.

\subsection{Journals with the Most Contribution in the Biofuels Field}

The Table 3 shows the list of articles with more than 50 citations in the biofuels field. The search criteria considered within the abstract, the keyword South Africa, for this reason, five articles were discarded from the initial analysis. The most frequently cited article was "Investigation of combined effect of nitrogen, phosphorus and iron on lipid productivity of microalgae Ankistrodesmus falcatus KJ671624 using response surface methodology", published in the "Biochemical Engineering Journal". The authors evaluated the effect of nutrients on the accumulation of lipids in Ankistrodesmus falcatus KJ671624 and determined its potential as a feedstock to obtain biodiesel (Singh et al., 2015). The second most frequently cited article was "Novel zeolite $\mathrm{Na}-\mathrm{X}$ synthesized from fly ash as a heterogeneous catalyst in biodiesel production", published in the journal "Catalysis Today". The authors evaluated catalysts for the production of biodiesel from sunflower oil (Babajide et al., 2012). The third paper most cited was" Multi-product biorefineries from lignocelluloses: A pathway to revitalisation of the sugar industry?", the authors simulations have been developed to gain a better understanding of the potential for product diversification in the sugarcane industry by means of biorefineries (Farzad et al., 2017). The fourth article most cited was "Effects of parameters affecting biomass yield and thermal behaviour of Chlorella vulgaris", where the authors determined the biofuel potential of a microalgae strain by subjecting it to variations in $\mathrm{CO}_{2}$ and nutrient concentrations and to study the thermal behaviour of algal biomass during pyrolysis using TGA (Bhola et al., 2011). The review most cited was "The potential of cassava biomass and applicable technologies for sustainable biogas production in South Africa: A review" published in "Renewable and Sustainable Energy Reviews" (Okudoh et al., 2014). The most cited articles include biodiesel, biogas and bioethanol topics and they were published 
Table 2: The top 15 biofuels journals used by South Africa researchers

\begin{tabular}{|c|c|c|c|c|c|}
\hline Source title & TP & TC & TC/TP & SJR (2019) & Quartile \\
\hline Journal of Energy in Southern Africa & 12 & 41 & 3.42 & 0.352 & Q2 \\
\hline Lecture Notes in Engineering and Computer Science & 12 & 14 & 1.17 & 0.19 & no assigned \\
\hline Biomass and Bioenergy & 10 & 173 & 17.30 & 1.11 & Q1 \\
\hline Renewable and Sustainable Energy Reviews & 9 & 314 & 34.89 & 3.632 & Q1 \\
\hline Agrekon & 8 & 30 & 3.75 & 0.377 & Q2 \\
\hline South African Journal of Science & 7 & 92 & 13.14 & 0.356 & Q2 \\
\hline Journal of Cleaner Production & 6 & 148 & 24.67 & 1.886 & Q1 \\
\hline South African Journal of Botany & 6 & 109 & 18.17 & 0.479 & Q2 \\
\hline Development Southern Africa & 5 & 8 & 1.60 & 0.384 & Q2 \\
\hline World Petroleum Congress Proceedings & 5 & 0 & 0.00 & \multicolumn{2}{|c|}{ Discontinued in Scopus } \\
\hline Bioresource Technology & 4 & 160 & 40.00 & 2.43 & Q1 \\
\hline Waste Management & 4 & 91 & 22.75 & 1.634 & Q1 \\
\hline Biofuels Bioproducts and Biorefining & 4 & 78 & 19.50 & 1.14 & Q1 \\
\hline Energy Policy & 4 & 76 & 19.00 & 2.168 & Q1 \\
\hline Water SA & 4 & 64 & 16.00 & 0.336 & Q3 \\
\hline
\end{tabular}

TP: Total of publications, TC: Total of citations

Table 3: Top 10 most cited document

\begin{tabular}{|c|c|c|c|c|}
\hline Title & Source title & Reference/DOI & $\begin{array}{l}\text { University (corresponding author } \\
\text { or first author)/countries }\end{array}$ & TC \\
\hline $\begin{array}{l}\text { Investigation of combined effect of } \\
\text { nitrogen, phosphorus and iron on lipid } \\
\text { productivity of microalgae Ankistrodesmus } \\
\text { falcatus KJ } 671624 \text { using response surface } \\
\text { methodology }\end{array}$ & $\begin{array}{l}\text { Biochemical } \\
\text { Engineering Journal }\end{array}$ & $\begin{array}{l}\text { Singh et al., 2015, doi:10.1016/j. } \\
\text { bej.2014.10.019 }\end{array}$ & $\begin{array}{l}\text { Institute for Water and Wastewater } \\
\text { Technology, Durban University of } \\
\text { Technology/ South Africa }\end{array}$ & 99 \\
\hline $\begin{array}{l}\text { Novel zeolite Na-X synthesized from } \\
\text { fly ash as a heterogeneous catalyst in } \\
\text { biodiesel production }\end{array}$ & Catalysis Today & $\begin{array}{l}\text { Babajide et al., 2012, } \\
\text { doi:10.1016/j.cattod.2012.04.044 }\end{array}$ & $\begin{array}{l}\text { Environmental and Nano Sciences } \\
\text { Group, Chemistry Department, } \\
\text { University of the Western Cape/ } \\
\text { South Africa }\end{array}$ & 86 \\
\hline $\begin{array}{l}\text { Multi-product biorefineries from } \\
\text { lignocelluloses: A pathway to } \\
\text { revitalisation of the sugar industry? }\end{array}$ & $\begin{array}{l}\text { Biotechnology for } \\
\text { Biofuels }\end{array}$ & $\begin{array}{l}\text { Farzad et al., 2017, doi:10.1186/ } \\
\text { s13068-017-0761-9 }\end{array}$ & $\begin{array}{l}\text { Department of Process } \\
\text { Engineering, Stellenbosch } \\
\text { University/South Africa }\end{array}$ & 81 \\
\hline $\begin{array}{l}\text { Effects of parameters affecting biomass } \\
\text { yield and thermal behaviour of Chlorella } \\
\text { vulgaris }\end{array}$ & $\begin{array}{l}\text { Journal of } \\
\text { Bioscience and } \\
\text { Bioengineering }\end{array}$ & $\begin{array}{l}\text { Bhola et al., 2011, doi:10.1016/j. } \\
\text { jbiosc.2010.11.006 }\end{array}$ & $\begin{array}{l}\text { Institute for Water and Wastewater } \\
\text { Technology, Durban University of } \\
\text { Technology/South Africa and India }\end{array}$ & 80 \\
\hline $\begin{array}{l}\text { The potential of cassava biomass and } \\
\text { applicable technologies for sustainable } \\
\text { biogas production in South Africa: A review }\end{array}$ & $\begin{array}{l}\text { Renewable and } \\
\text { Sustainable Energy } \\
\text { Reviews }\end{array}$ & $\begin{array}{l}\text { Okudoh et al., 2014, } \\
\text { doi:10.1016/j.rser.2014.07.142 }\end{array}$ & $\begin{array}{l}\text { Faculty of Applied Sciences, } \\
\text { Cape Peninsula University of } \\
\text { Technology/South Africa }\end{array}$ & 65 \\
\hline $\begin{array}{l}2^{\text {nd }} \text { Generation biofuels a sure bet? A life } \\
\text { cycle assessment of how things could go } \\
\text { wrong }\end{array}$ & $\begin{array}{l}\text { Journal of cleaner } \\
\text { production }\end{array}$ & $\begin{array}{l}\text { Melamu and von Bloottnitz, } \\
\text { 2011, doi:10.1016/j. } \\
\text { jclepro.2010.08.021 }\end{array}$ & $\begin{array}{l}\text { University of Cape Town, } \\
\text { Department of Chemical } \\
\text { Engineering/South Africa }\end{array}$ & \\
\hline $\begin{array}{l}\text { Ethnopharmacology and toxicity of } \\
\text { Jatropha curcas L. (Euphorbiaceae): A } \\
\text { review. }\end{array}$ & $\begin{array}{l}\text { South African } \\
\text { Journal of Botany }\end{array}$ & $\begin{array}{l}\text { Abdelgadir and Van Staden, } \\
\text { 2013, doi:10.1016/j. } \\
\text { sajb.2013.07.021 }\end{array}$ & $\begin{array}{l}\text { Research Centre for Plant Growth } \\
\text { and Development, School of Life } \\
\text { Sciences, University of KwaZulu- } \\
\text { Natal Pietermaritzburg/ South Africa }\end{array}$ & 55 \\
\hline $\begin{array}{l}\text { The current bioenergy production potential } \\
\text { of semi-arid and arid regions in sub- } \\
\text { Saharan Africa }\end{array}$ & $\begin{array}{l}\text { Biomass and } \\
\text { Bioenergy }\end{array}$ & $\begin{array}{l}\text { Wicke et al., 2011, doi:10.1016/j. } \\
\text { biombioe.2011.03.010 }\end{array}$ & $\begin{array}{l}\text { Department of Science, Technology } \\
\text { and Society, Copernicus Institute, } \\
\text { Utrecht University/Netherlands and } \\
\text { South Africa }\end{array}$ & 53 \\
\hline
\end{tabular}

after 2010 in journals with a high impact factor. Also, Citations is the most common method used as a measure of influence of an author (Briones-Bitar et al., 2020).

\subsection{Most Productive Authors in the Field of Biofuels}

Table 4 shows the authors who had more than 5 publications in the area of biofuels. The author with the most documents was Mbohwa, who published 13 conference papers, an article titled "Experimental and feasibility assessment of biogas production by anaerobic digestion of fruit and vegetable waste from Joburg market" that has 13 citations, in addition to a review "Development of biofuels in South Africa: Challenges and opportunities" published in "Renewable and Sustainable Energy Reviews" that has 48 citations. The second author most productive was Brent, who published 7 articles, 1 review and 2 conference papers.

\subsection{Publishing Institutions}

Of the 160 institutions found in the search box, $60 \%$ of the total publications in South Africa are concentrated in the top 20, Table 4. Stellenbosch University, the University of Johannesburg and The Council for Scientific and Industrial Research are the top three institutions. As can be seen in Table 5, the most influential institution in the biofuels field is Stellenbosch University, in fact it contributes 
Table 4: Most productive authors in biofuels (Scopus database)

\begin{tabular}{|c|c|c|c|}
\hline Ranking & Author & TP & Institution/ Country \\
\hline 1 & Mbohwa C & 15 & $\begin{array}{l}\text { University of Johannesburg, } \\
\text { Johannesburg, South Africa }\end{array}$ \\
\hline 2 & Brent A & 10 & $\begin{array}{l}\text { Stellenbosch University, } \\
\text { Stellenbosch, South Africa }\end{array}$ \\
\hline 3 & Amigum B & 7 & $\begin{array}{l}\text { National Biotechnology } \\
\text { Development Agency, Nigeria } \\
(* \text { Co-working) }\end{array}$ \\
\hline 4 & Görgens, J.F. & 7 & $\begin{array}{l}\text { Stellenbosch University, } \\
\text { Stellenbosch, South Africa }\end{array}$ \\
\hline 5 & Bux, F. & 6 & $\begin{array}{l}\text { Durban University of Technology, } \\
\text { Durban, South Africa }\end{array}$ \\
\hline 6 & Chowdhury, S. & 6 & $\begin{array}{l}\text { University of Cape Town, Cape } \\
\text { Town, South Africa }\end{array}$ \\
\hline 7 & Musango, J.K. & 6 & $\begin{array}{l}\text { Stellenbosch University, } \\
\text { Stellenbosch, South Africa }\end{array}$ \\
\hline 8 & Muzenda, E. & 6 & $\begin{array}{l}\text { College of Engineering } \\
\text { and Technology Botswana } \\
\text { International University of } \\
\text { Science and Technology Palapye } \\
\text { Botswana, United States }\end{array}$ \\
\hline 9 & Makaka, G. & 5 & $\begin{array}{l}\text { University of Fort Hare, Alice, } \\
\text { South Africa }\end{array}$ \\
\hline 10 & Pradhan, A. & 5 & $\begin{array}{l}\text { University of Johannesburg, } \\
\text { Johannesburg, South Africa }\end{array}$ \\
\hline 11 & Trois, C. & 5 & $\begin{array}{l}\text { University of KwaZulu-Natal, } \\
\text { Durban, South Africa }\end{array}$ \\
\hline
\end{tabular}

Table 5: Most prolific institutions in biofuels publishing in South Africa

\begin{tabular}{llcc} 
Ranking & TP & University \\
\hline 1 & Stellenbosch University & 35 & 7.22 \\
2 & University of Johannesburg & 32 & 6.60 \\
3 & The Council for Scientific and Industrial & 32 & 6.60 \\
& Research & 30 & 6.19 \\
4 & University of KwaZulu-Natal & 29 & 5.98 \\
5 & University of Cape Town & 22 & 4.54 \\
6 & Universiteit van Pretoria & 17 & 3.51 \\
7 & University of Witwatersrand & 12 & 2.47 \\
8 & University of South Africa & 12 & 2.47 \\
9 & Durban University of Technology & 12 & 2.47 \\
10 & North-West University & 8 & 1.65 \\
11 & University of Witwatersrand, School of & & \\
& Chemical and Metallurgical Engineering & 7 & 1.44 \\
12 & Agricultural Research Council, Pretoria & 7 & 1.44 \\
13 & University of Fort Hare & 5 & 1.03 \\
14 & Cape Peninsula University of Technology & 5 & 1.03 \\
15 & South African Sugarcane Research Institute & 5 & 1.03 \\
16 & Tshwane University of Technology & 5 & 1.03 \\
17 & University of the Western Cape & 5 & 1.03 \\
18 & University of Venda & 4 & 0.82 \\
19 & University of Zululand & 4 & 0.82 \\
20 & University of Limpopo & & \\
\hline
\end{tabular}

with $7.22 \%$ of the publications. Of the total of publications, 95 institutions contributed only with 1 publication, 34 institutions contributed with 2 publications, 10 institutions contributed with 3 publications and 4 institutions contributed with 4 .

\subsection{Most Relevant Subjects}

In the Scopus database, the 352 publications are grouped into 20 different subject categories. The contributions of the top
Table 6: The top 20 most productive subjects

\begin{tabular}{lcc} 
Area & TP & TC \\
Energy & 135 & 1790 \\
Environmental Science & 120 & 1452 \\
Agricultural and Biological Sciences & 70 & 779 \\
Engineering & 67 & 551 \\
Chemical Engineering & 46 & 901 \\
Social Sciences & 44 & 263 \\
Computer Science & 35 & 101 \\
Biochemistry, Genetics and Molecular Biology & 26 & 547 \\
Earth and Planetary Sciences & 24 & 238 \\
Chemistry & 23 & 623 \\
Business, Management and Accounting & 21 & 207 \\
Immunology and Microbiology & 16 & 340 \\
Economics, Econometrics and Finance & 14 & 40 \\
Materials Science & 8 & 96 \\
Physics and Astronomy & 6 & 20 \\
Medicine & 5 & 45 \\
Decision Sciences & 4 & 4 \\
Mathematics & 4 & 19 \\
Multidisciplinary & 3 & 18 \\
\hline
\end{tabular}

20 subjects in biofuels research from 1979 to 2020 are shown in Table 6. Energy is the most popular topic, which has 135 publications and 1790 citations. Environmental Science, with 120 publications and 1452 citations, occupied the second place. The number of the top 5 subjects account for $65 \%$ of the total of publications.

\subsection{Keywords Co-occurrence Analysis}

Keywords represent the main contents of existing research and depict the area studied within the boundaries of a given domain (Chàefer et al., 2021). The main topics depicted within the selected field are presented in Figure 3, the VOSviewer software was used for the construction of the co-occurrence map.

Co-occurring keywords used by authors were retrieved and analysed as shown in Figure 3, these keywords were grouped into 6 coloured clusters according to similarities in the areas of research. The 10 most occurring keywords were "South Africa" (130 occurrences), "biofuel" (76 occurrences), "biofuels" (74 occurrences), "biogas" (64 occurrences), "ethanol" (43 occurrences), "biomass" (42 occurrences), "biodiesel" (41 occurrences), "greenhouse gases" (29 occurrences), "sustainable development" (28 occurrences) and "anaerobic digestion" (74 occurrences). There are many clusters (7) in the map, which shows the diversification of research directions, the big frames represent the influential countries. The links between frames represent the cooperative relationship among institutes and the distance between the nodes and the thickness of the links represent the level of cooperation among countries (Liao et al., 2018). The Figure 2 illustrates the relation between keywords, the red cluster is composed of 60 items and relates to the biogas, gas emissions and anaerobic digestion line of research. The green cluster is composed of 37 items and relates to the bioethanol, feedstock and treatments line of research. The red cluster is composed of 34 items and relates to the biofuels, crops and food security line of research. A strong interrelated line of research with the yellow cluster is directly related to South Africa and the biodiesel. The pink cluster has 21 items and relates to the economic and social 
Figure 3: Network visualization maps the keywords of biofuels research in South Africa

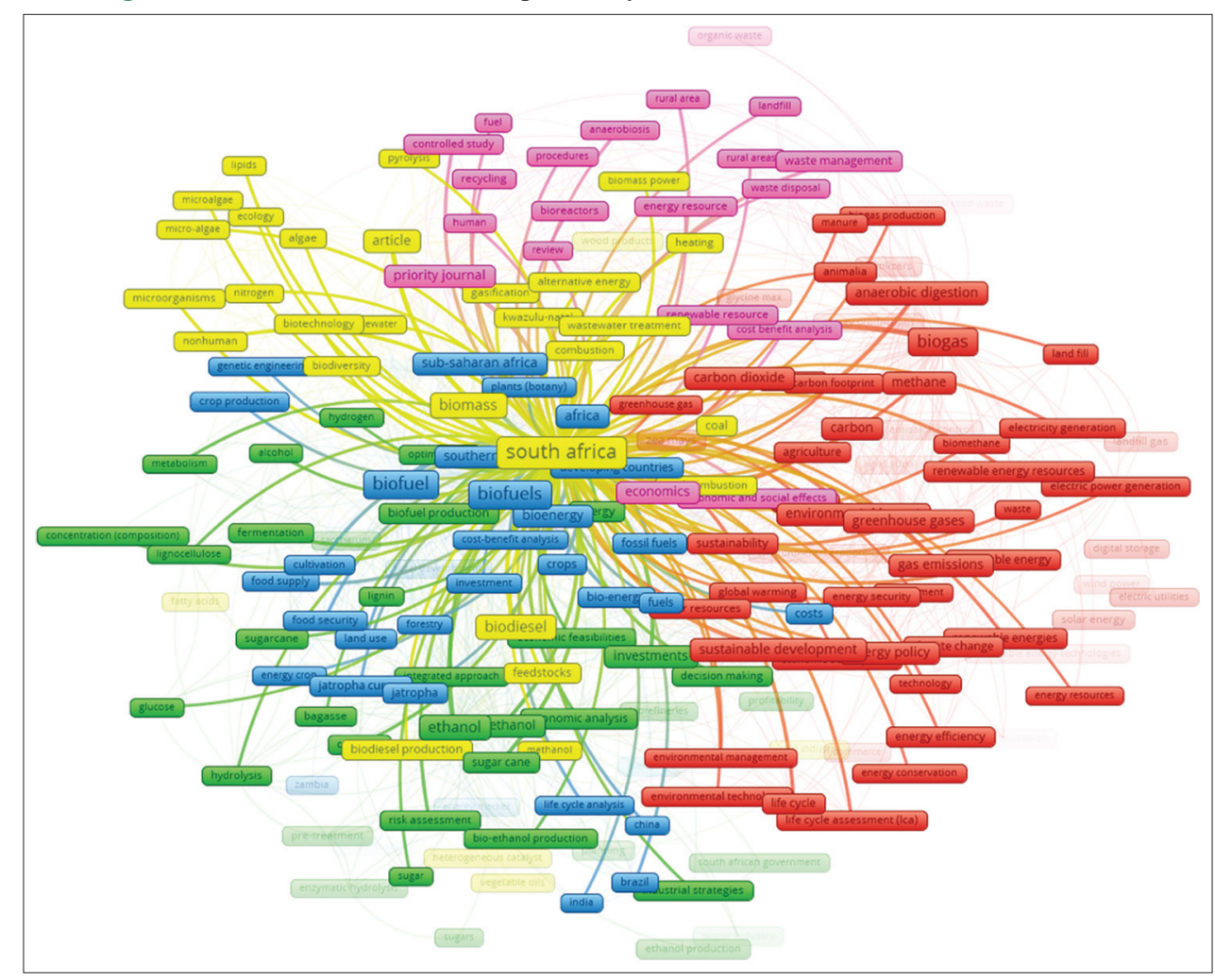

effect line of research. The blue cluster is composed of 1 item (blending).

In general, the results of this study showed a growth in the last 10 years, which can be attributed to the global development of science around the world and the social and environmental awareness of society. The development of biofuel research is the result of the public policies of various countries, including South Africa, which promote the reduction of greenhouse gas emissions and to some extent have developed the technology to generate the energy transition of fossil fuels to fuels considered environmentally friendly. Considering the number of institutions and the leadership of the authors, the need for collaboration is visualized to form a greater number of research clusters that promote interaction to diversify the forms of biofuels according to the biomass resources of South Africa.

In the bibliometric analysis was reported some possible limitations, in this case, it can be the gap in conception where the top authors do not reference all the most essential citations and the database is not the only one that concentrates the information of the publications of the study area (Nobanee et al., 2021).

\section{CONCLUSION}

This study examined the evolution of scientific research in the biofuels field between 1979 and 2020, based on publications in the Scopus database. The main findings are summarised as follows: The Stellenbosch University and University of Johannesburg were the most productive institutions in terms of publications of biofuels, the authors Brent A. and Mbohwa C. are referents in these institutions according to the search criteria. The study is the first attempt to conduct a comprehensive review of the biofuels in South Africa. Biochemical Engineering Journal, Catalysis Today and Biotechnology for Biofuels were the top three journals, and Energy, Environmental Science and Agricultural and Biological Sciences were the three most productive subjects. The results of this bibliometric analysis enhance knowledge of the evolution on the biofuels field in South Africa with an overview of the relevant literature and its authors.

\section{ACKNOWLEDGMENTS}

The authors thank the Michoacan University of San Nicolas of Hidalgo for access to the database.

\section{REFERENCES}

Abdelgadir, H.A., van Staden, J. (2013), Ethnobotany, ethnopharmacology and toxicity of Jatropha curcas L. (Euphorbiaceae): A review. South African Journal of Botany, 88, 204-218.

Adedayo, H.B., Adio, S.A., Oboirien, B.O. (2021), Energy research in Nigeria: A bibliometric analysis. Energy Strategy Reviews, 34, 100629.

Albashabsheh, N.T., Stamm, J.L.H. (2021), Optimization of lignocellulosic biomass-to-biofuel supply chains with densification: Literature review. Biomass and Bioenergy, 144, 105888.

Babajide, O., Musyoka, N., Petrik, L., Ameer, F. (2012), Novel zeolite $\mathrm{Na}-\mathrm{X}$ synthesized from fly ash as a heterogeneous catalyst in biodiesel production. Catalysis Today, 190(1), 54-60.

Beigzadeh, M., Pourfayaz, F., Ghazvini, M., Ahmadi, M.H. (2021), Energy and exergy analyses of solid oxide fuel cell-gas turbine hybrid systems fed by different renewable biofuels: A comparative 
study. Journal of Cleaner Production, 280, 124383.

Bhola, V., Desikan, R., Santosh, S.K., Subburamu, K., Sanniyasi, E., Bux, F. (2011), Effects of parameters affecting biomass yield and thermal behaviour of Chlorella vulgaris. Journal of Bioscience and Bioengineering, 111(3), 377-382.

Bórawski, P., Bełdycka-Bórawska, A., Szymańska, E.J., Jankowski, K.J., Dubis, B., Dunn, J.W. (2019), Development of renewable energy sources market and biofuels in The European Union. Journal of Cleaner Production, 228, 467-484.

Briones-Bitar, J., Carrión-Mero, P., Montalván-Burbano, N., MoranteCarballo, F. (2020), Rockfall research: A bibliometric analysis and future trends. Geosciences, 10(10), 403.

Chàfer, M., Cabeza, L.F., Pisello, A.L., Tan, C.L., Wong, N.H. (2021), Trends and gaps in global research of greenery systems through a bibliometric analysis. Sustainable Cities and Society, 65, 102608.

Chuang, K.Y., Chuang, Y.C., Ho, M., Ho, Y.S. (2011), Bibliometric analysis of public health research in Africa: The overall trend and regional comparisons. South African Journal of Science, 107(5/6), $1-6$.

Ebadian, M., van Dyk, S., McMillan, J.D., Saddler, J. (2020), Biofuels policies that have encouraged their production and use: An international perspective. Energy Policy, 147, 111906.

EdwinGeo, V., Fol, G., Aloui, F., Thiyagarajan, S., Stanley, M.J., Sonthalia, A., Brindhadevi, K., Saravanan, C.G. (2021), Experimental analysis to reduce $\mathrm{CO}_{2}$ and other emissions of CRDI CI engine using low viscous biofuels. Fuel, 283, 118829.

Farzad, S., Mandegari, M.A., Guo, M., Haigh, K.F., Shah, N., Görgens, J.F. (2017), Multi-product biorefineries from lignocelluloses: A pathway to revitalisation of the sugar industry? Biotechnology for Biofuels, $10(1), 87$.

Jiménez-Islas, D., Pérez-Romero, M.E., Aranzolo-Sánchez, P.A. (2021a), The rate of production in scientific publications of biofuels in Latin America Countries. Prospectiva, 19(1), 1-13.

Jiménez-Islas, D., Pérez-Romero, M.E., Rivera-Ríos, J.M., FloresRomero, M.B. (2021b), A bibliometric analysis of sugar beet for production of biofuels. International Journal of Energy Economics and Policy, 11(3), 57-63.

Liao, H., Tang, M., Luo, L., Li, C., Chiclana, F., Zeng, X.J. (2018), A bibliometric analysis and visualization of medical big data research. Sustainability, 10(2), 166.

Makhoba, X., Pouris, A. (2017), Bibliometric analysis of the development of nanoscience research in South Africa. South African Journal of Science, 113(11/12), 1-9.

Melamu, R., von Blottnitz, H. (2011), $2^{\text {nd }}$ Generation biofuels a sure bet? A life cycle assessment of how things could go wrong. Journal of Cleaner Production, 19(2-3), 138-144.

Merigó, J.M., Gil-Lafuente, A.M., Yager, R.R. (2015), An overview of fuzzy research with bibliometric indicators. Applied Soft Computing, 27, 420-433.

Merigó, J.M., Yang, J.B. (2016), Accounting research: A bibliometric analysis. Australian Accounting Review, 27(1), 71-100.

Nobanee, H., Al Hamadi, F.Y., Abdulaziz, F.A., Abukarsh, L.S., Alqahtani, A.F., AlSubaey, S.K., Alqahtani, S.M., Almansoori, H.A. (2021), A bibliometric analysis of sustainability and risk management. Sustainability, 13(6), 3277.

Okudoh, V., Trois, C., Workneh, T., Schmidt, S. (2014), The potential of cassava biomass and applicable technologies for sustainable biogas production in South Africa: A review. Renewable and Sustainable Energy Reviews, 39, 1035-1052.

Pouris, A. (2008), Energy and fuels research in South African Universities: A comparative assessment. The Open Information Science Journal, 1(1), 1-9.

Pouris, A. (2016), A bibliometric assessment of energy research in South Africa. South African Journal of Science, 112(11/12), 1-8.

Pradhan, A., Mbohwa, C. (2014), Development of biofuels in South Africa: Challenges and opportunities. Renewable and Sustainable Energy Reviews, 39, 1089-1100.

Sameeroddin, M., Deshmukh, M.K.G., Viswa, G., Sattar, M.A. (2021), Renewable Energy: Fuel from Biomass, Production of Ethanol from Various Sustainable Sources by Fermentation Process, Materials Today: Proceedings.

Singh, P., Guldhe, A., Kumari, S., Rawat, I., Bux, F. (2015), Investigation of combined effect of nitrogen, phosphorus and iron on lipid productivity of microalgae Ankistrodesmus falcatus KJ671624 using response surface methodology. Biochemical Engineering Journal, 94, 22-29.

Wicke, B., Smeets, E., Watson, H., Faaij, A. (2011), The current bioenergy production potential of semi-arid and arid regions in Sub-Saharan Africa. Biomass and Bioenergy, 35(7), 2773-2786.

Zhao, Y., Jiang, Y., Zhou, Z., Yang, Z. (2021), Global trends in karstrelated studies from 1990 to 2016: A bibliometric analysis. Alexandria Engineering Journal, 60(2), 2551-2562. 